\title{
The benefits and risks of financial globalisation: evidence from the European transition economies
}

\begin{abstract}
This study investigates whether the sizable and persistent current account deficits of European transition economies have been fuelling higher rates of economic growth during the last fifteen years. It employs a Barro-type growth model that encompasses a core set of growth determinants and control variables in order to examine whether episodes of current account reversals and sudden stops in international capital inflows have had detrimental effects on economic growth. The empirical specification uses data for 27 advanced economies and 13 European transition economies. Large and persistent current account deficits have been associated with gains from inter-temporal trade and, therefore, have served as an engine of economic growth. The evidence seems to support the proposition that current account deficits in transition economies have, on average, generated moderate growth-conducive effects. The empirical work also produces limited evidence that current account reversals and sudden stops of net capital inflows have been associated with growth slowdown.
\end{abstract}

Keywords: inter-temporal trade, economic growth, external current account sustainability, net foreign assets.

\section{Introduction}

The dramatic increase in inter-temporal trade in transition economies during the late 1990s and early 2000s, as seen by widening current account deficits and deteriorating net foreign asset positions, has ignited considerable interest in external sustainability analysis. Conventional wisdom suggests that current account deficits exceeding $5 \%$ of GDP are a potential danger to macroeconomic and financial stability, but current account payment balances in most European transition economies have been seeing levels well above $10 \%$ of GDP. Given their impressive rates of economic growth during the 2000 s, the theoretical and empirical guidance - that the inevitable adjustment (the socalled 'current account reversal') could have devastating macroeconomic implications - seemed no longer important. The most striking example was Latvia, which was running current account deficits of $22.5 \%$ of GDP in spite of real GDP growth of $10 \%$ in 2007 (IMF, 2009). This is exactly the country that was hit particularly severely by the global economic crisis, with a projected negative real GDP growth of $18 \%$ in 2009 .

In order to examine the potentially detrimental effects of current account adjustment episodes on economic growth, this study develops a Barro-type growth model. It also aims to investigate whether the sizable and persistent current account deficits of European transition economies have been fuelling higher rates of economic growth during 
the last fifteen years. Unlike prior research, the model incorporates a core set of explanatory variables and a number of potentially relevant growth determinants that also act as conditioning factors in current account behaviour. The empirical strategy rests on an unbalanced fixed-effects estimation of panel data, using data for 27 advanced economies and 13 European transition economies organised at five-, four- and threeyear intervals over the 1976-2005 period.

The second section explores the links between international finance and economic growth from the perspective both of flow (via widening current account deficits) and of stock (via deteriorating net foreign asset positions). Both aspects reflect the quantities of foreign capital that, according to neoclassical theory, should flow from capitalabundant to capital-scarce recipient countries (Lucas, 1990). The third section outlines the analytical framework for an augmented growth model, while the next discusses the empirical formulation and investigates the data issues. The fifth section elaborates the diagnostic tests and estimation results and the final section conveys concluding remarks and policy recommendations.

\section{The nexus between international finance and economic growth}

The hypothesised supply-side impact of external current account deficits may operate through several channels. The external imbalances encourage advances in the stock of knowledge through the technological content embedded in goods imported for productive use. Furthermore, their sources of financing (e.g. the net inflows of foreign direct investment and portfolio investment) augment the scarce resources of the recipient country and facilitate domestic capital formation. The sources of financing may matter not only in terms of the distinction between debt- and non-debt-creating flows but, even more, in terms of their differential impact on a country's stock of physical capital, its pool of knowledge and its growth prospects.

On the other hand, Lane and Milesi-Ferretti (2006) argue that the benefits of international financial integration are tied to the gross holdings of foreign assets and liabilities rather than to capital flows. In essence, the stock adjustment approach to external disequilibrium analysis presumes that it is not the current account but the net foreign asset position per se that matters most (Calderón et al, 2000). Net foreign assets are defined as the difference between the stock of foreign assets held by domestic residents and the stock of domestic liabilities held by foreign residents. The changes in net foreign asset positions reflect not only the current account balance but also changes in valuation. For instance, despite officially registered large and persistent current account deficits, an appreciating currency may, in fact, improve a country's net foreign asset position and stimulate further intertemporal trade. The hypothesised growth effects of widening net foreign asset positions could be due to the positive externalities of an alreadyaccumulated stock of foreign investment (especially foreign direct investment), corrected for valuation gains or losses.

Another argument for the focus on net foreign asset positions, in addition to current account balances, is the disconnect between the two variables in the era of increasing international capital mobility. Table 1 illustrates that the magnitude of the correlation coefficient has declined over time; this is in line with expectations that the valuation channel is gaining in importance with greater financial integration. For instance, during 
the 1991-2000 period, the correlation coefficient between the current account balances and the changes in net foreign asset positions is 0.13 (based on 363 pairs of observations in the sample of forty countries). The test for the significance of the Pearson productmoment correlation coefficient indicates that this is not significantly different from zero, at least at the $1 \%$ level (p-value is 0.013 ).

Table 1 - Correlation coefficients between current account balances and changes in net foreign assets in a sample of 40 economies (1971-2000)

\begin{tabular}{|l|c|c|c|c|}
\hline & $\begin{array}{c}\text { Coefficient of } \\
\text { correlation }\end{array}$ & $\begin{array}{c}\text { Pairs of } \\
\text { observations }\end{array}$ & p-value & t-stat \\
\hline $1971-1980$ & 0.5738 & 200 & 0.000 & 9.86 \\
\hline $1981-1990$ & 0.4447 & 260 & 0.000 & 7.98 \\
\hline $1991-2000$ & 0.1298 & 363 & 0.013 & 2.49 \\
\hline $1971-2000$ & 0.2844 & 823 & 0.000 & 9.30 \\
\hline
\end{tabular}

Note: The p-values and t-statistics are based on the test for the significance of the Pearson productmoment correlation coefficient.

Casual inspection of the net foreign asset positions of central and eastern European and south-east European transition economies reveals that transition countries have embarked on rapid international financial diversification and have also opted for larger stocks of external liabilities (Figure 1). Their net foreign asset positions (measured as time-varying GDP-weighted averages) have substantially deteriorated in the last decade. Another interesting finding is that the thirteen advanced EU economies were, as a group, also a net debtor between 1994 and 2004. 
Figure 1 - Net foreign asset positions of advanced EU economies and central and south-east European transition economies, 1994-2004 (GDP-weighted averages)

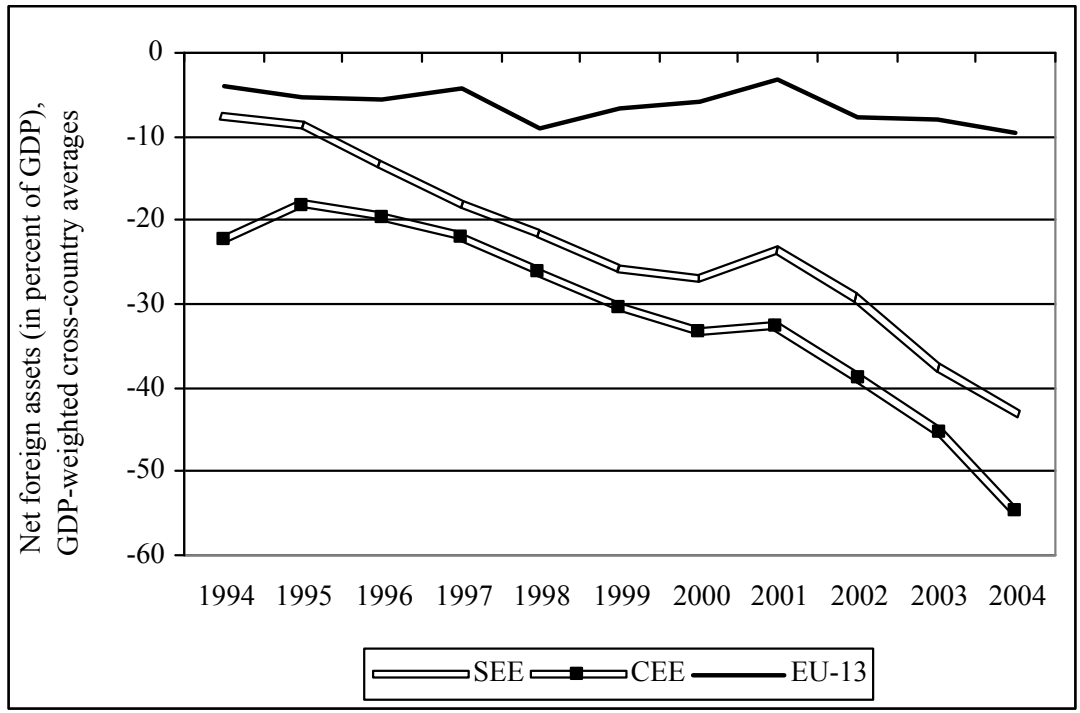

Source: Based on the international dataset of Lane and Milesi-Ferretti (2006).

However, the applied work is still inconclusive with respect to the nexus between international finance and economic growth. Bhagwati (1998) underscores that the risks of free capital mobility often outweigh the benefits of international capital inflows for recipient countries. Kose et al. (2006) find little robust evidence in favour of the growth benefits of increasing financial integration. Prasad et al. (2007) report that 61 nontransition developing countries that have relied heavily on foreign finance have not grown faster in the long-run, mainly because of their limited capacity to absorb foreign capital. Even the scarce empirical work on transition economies finds that FDI over the 1994-2001 period has had a counter-intuitive, highly significant and consistently negative effect (e.g. Mencinger, 2003). Contrary to these findings, Abiad et al. (2007) document a 'downhill' flow of international capital from advanced to transition economies in the European region which has supported their real convergence.

In order to examine the potential growth effects of current account deficits, net foreign asset positions and current account adjustment episodes, the following section develops an analytical framework for a model that also includes standard growth determinants.

\section{Specification of a growth model}

The analytical framework for the growth model builds upon the investigation by Salai-Martin et al. (2004) of the statistical significance of growth determinants. Their methodology is based on a Bayesian averaging of classical estimates and, in particular, 
aims at a narrowing of the gap between growth theories and the empirical work. This particular study examines the relationship between economic growth and a list of 67 explanatory variables (identified in cross-country growth regressions from articles in peer-reviewed or refereed journals) using data for 88 countries during the 1960-1996 period. From the narrow list of variables that is found to be significantly and robustly correlated at least partially with economic growth (eighteen, in particular) in the Salai-Martin et al. research, five have been selected as core explanatory variables in the empirical model adopted in this study.

An important caveat with regard to the core of the empirical model is that it does not take full account of the propositions of influential neo-institutionalist theories. The lack of sufficient time depth of the published series of computed variables which captures the role of institutions (e.g. indices of institutional quality) precludes such an investigation. Even so, the assumption that their effect is partly felt through GDP per capita may not be implausible. More precisely, if the improved institutional quality is growth conducive, then its effect will be partly reflected in rising private sector productivity and higher GDP per capita.

The inclusion of an initial level of GDP per capita tests the propositions of the betaconvergence hypothesis, implying that low income countries tend to display higher rates of growth. Hence, the expected sign of the coefficient on this variable is negative.

Average years of schooling are a far-from-perfect proxy for a country's human capital but, given the lack of alternative education indicators, this measure plays a satisfactory role in many growth regressions. For instance, the indicator does not capture changes made either in the quality of education or in the capacity of the education system to meet the skill composition of labour demand. Comparable estimates are pulled from the Barro and Lee (2000) international dataset on educational attainment and refer to the population over 25. An additional limitation of the measure of average years of schooling is that it:

Assumes unrealistically that a year of education adds a constant quantity of human capital, whether undertaken by a primary pupil or a college student. (Barro and Lee, 2000, p. 16)

Nevertheless, the expected sign is positive since human capital formation is expected to be associated with growth-conducive effects, ceteris paribus.

The relationship between population size and economic growth continues to raise controversies in modern development economics. 'Population pessimists' argue that population growth inhibits economic development since a greater population involves public costs of raising children, requires additional production capital per worker, etc. (see Johnson and Lee, 1987). Mainstream neoclassical growth models predict that population growth has the same effect as depreciation: an increased supply of labour reduces the capital stock per unit of labour. According to this class of models, the steady-state level of output will increase if the rate of population growth decelerates, under the ceteris paribus assumption. On the other hand, the 'population optimists' camp conjectures that population growth in the long run brings: 
Improvement of productivity through both the contribution of new ideas and also the learningby-doing consequent upon increased production volume. (Simon, 1987, p. 168)

In contrast with neoclassical growth models, endogenous growth theories (e.g. Lucas, 1988, 1990; Rebelo, 1991; Romer, 1990, 1994) emphasise that the non-rivalry of new ideas accompanied by population growth are strong engines of economic growth. The literature is inconclusive with respect to the expected sign of this variable, so it would be premature to specify a priori expectations. The use of population growth as a growth determinant could also be of limited value if dramatic changes in a country's age composition are taking place.

Greater exposure to globalisation, inter alia, as seen by the degree of trade openness, is an important indicator of a country's ability to achieve greater specialisation and to cope with external competitive pressures. Additionally, trade openness is associated with benefits from technology spillovers, particularly from the knowledge embedded in imported capital goods. Trade theories and endogenous growth models suggest a positive association between trade openness and economic growth, but the empirical literature does not speak with one voice. Despite the limited empirical evidence demonstrating that there is no systematic relationship between trade openness and growth, the expected sign on the coefficient of the trade openness variable (measured by the sum of a country's exports and imports) is positive in line with the theoretical guidance.

Lastly, the relative price of capital goods serves as a proxy for the cost of investment. This measure is constructed as a ratio between the price level of investment and the GDP deflator. The empirical studies seem to offer compelling evidence in favour of a strong negative relationship between the relative price of capital goods and investment (Jones, 1994; Restuccia and Urrutia, 2001; Collins and Williamson, 2001). The accumulation of physical capital is growth conducive, so the expected sign on the relative price of investment goods is also negative.

Given the particular interest in external imbalances and current account adjustment, current account balances and episodes of sudden stops and reversals are included together with the core empirical specification in order to investigate their partial correlation with economic growth. Such an empirical strategy might be at risk of distorting the 'true' influence of the current account balance, because there are other growth determinants that, simultaneously, are conditioning factors in current account behaviour. In that case, the model specified below would produce an estimated impact on the current account that is subject to omitted variable bias, given the correlation between the interest variable and the error term. Therefore, the list of potentially relevant variables is further extended by the inclusion of the additional determinants of growth that are also correlated with the current account balance.

Figure 2 presents the outlined analytical framework; these variables are general government consumption, net international capital flows (foreign direct and portfolio investment inflows) and age-dependency ratios. 
Figure 2 - The analytical framework of the augmented growth model

Core explanatory variables

Initial GDP per capita

Average years of schooling

Population growth

Trade openness

Relative price of investment
Fragility perspective on the current account adjustment

Dummy variables

Current account reversals

Sudden stops

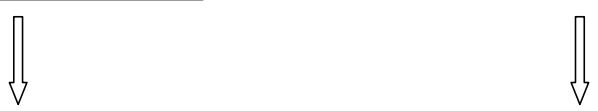

\section{Economic growth}

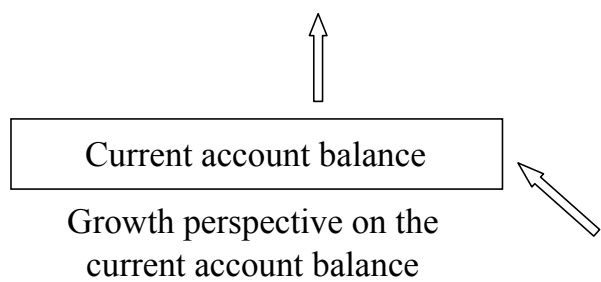

current account balance
General government consumption

Foreign direct investment, net

Portfolio investment, net

Net foreign asset position

Financial development

Age-dependency ratio

List of control variables

General government consumption expenditure is used in the growth literature as a measure of the size of government. Theory suggests that there is a certain threshold of government expenditure associated with the provision of core government functions beyond which further increases in government consumption spending are not expected to enhance the productivity of the private sector. In the empirical work, these thresholds are not directly observable and usually do not take into account the institutional differences between countries. In the endogenous growth model (the public goods model of productive government services) developed by Barro (1990), and extended by Barro and Sala-i-Martin (2001), the effect of government on growth involves two conflicting channels: the negative effect of taxation on the post-tax marginal product of capital; and the beneficial effect of the provision of public services. Despite theoretical inconclusiveness, the overwhelming empirical evidence suggests a negative association between government size and economic growth in the long run (e.g. Guseh, 1997; Dar and AmirKhalkhali, 2002).

The transition-related empirical literature on the growth impact of foreign capital inflows is also inconclusive. For instance, Campos and Kinoshita (2002) support the beneficial impact of FDI inflows on economic growth in 25 central and eastern Euro- 
pean and former Soviet Union transition economies. Broader panel data analysis of the impact of FDI in eight then EU candidate countries, conducted by Mencinger (2003), reveals no statistically significant relationship with domestic capital formation, but the presence of a highly significant and consistently negative effect on economic growth for the 1994-2001 period. The counter-intuitive findings are attributed to the prevalence of mergers and acquisitions in foreign investment inflows, whereas the use of foreign exchange proceeds has been hypothesised to be allocated to consumption and imports.

Empirical evidence of the effects of foreign portfolio investment is rather scarce, since the literature has been mainly FDI-centred. Even so, studies report either no statistically significant effect on economic growth (e.g. Edison et al. 2002) or the presence of a negative effect (e.g. Durham, 2004). The central message from a survey of the empirical literature on the growth impact of portfolio investment is that the results are highly sensitive to the different empirical specifications and techniques used. A priori expectations favour no systematic relationship between net foreign direct and portfolio investment and economic growth.

Financial development is another important variable that displays a consistent influence not only on short-term output fluctuations but also on growth prospects in the longer-term. Better-functioning financial markets and institutions exhibit an independent positive influence on economic growth (e.g. Easterly and Levine, 2001), but many empirical studies support a reverse causality between the two variables (Levine, 1997; Levine et al. 2000). This problem is addressed by treating financial development as an explanatory variable that enters the growth equation with values for the year preceding each multi-year non-overlapping interval. We use as an indicator of a country's financial development, the amount of private sector credit in deposit-based banks and other monetary institutions (expressed as a fraction of GDP). The data is from the financial structure dataset of the World Bank. In line with the theoretical guidance, the expected sign on the coefficient for the financial development proxy is positive.

Lastly, life-cycle and overlapping-generations theories underscore that a country's demographic profile may have profound effects on its economic growth. The standard empirical strategy has been to incorporate age composition through age-dependency ratios, which measure the demographic burden on a society. Age dependency is defined as the sum of the ratios of young dependency (defined as the share of the population between 0 and 14 in the total population) and old-age dependency (defined as the share of the population over 60 in the total population). The expected sign is negative, because a larger share of the non-working population imposes a demographic burden on the rate of economic growth.

In order to investigate the economic costs (in terms of output performance) of current account reversals and sudden stops, the model includes a dummy variable taking the value of 1 , if a current account reversal has occurred in the multi-year non-overlapping period, and 0 otherwise. Given the relatively small sample of countries, the preferred definition of a current account reversal episode rests on two criteria:

1. a current account deficit, prior to the external adjustment, of at least $3 \%$ of GDP

2. the magnitude of the reduction of the current account deficit to be at least $3 \%$ of GDP in the subsequent year. 
Edwards (2001) has demonstrated that external adjustments have negative effects on economic performance mainly because investments are affected by reduced external financing.

The implications of current account reversals can be rather sensitive to the definition employed so, in addition to the preferred one, two alternative descriptions are used. These more restrictive definitions of current account reversal episodes involve:

a) an initial current account deficit of at least $4 \%$ of GDP and the reduction of this ratio by at least $4 \%$ in one year (reversal type B)

b) an initial current account deficit of at least $5 \%$ of GDP and the reduction of this ratio by at least $5 \%$ in one year (reversal type $\mathrm{C}$ ).

Additional analysis focuses on the impact of sudden stops in external financing on the rates of economic growth. Net capital inflows are defined as the sum of net inflows of foreign direct investment, portfolio investment and loans and trade-related lending (expressed as a fraction of GDP). Data is pulled from the IMF's Balance of Payments Statistics database for each country. In empirical terms, a sudden stop is defined as a reduction of net international capital inflows of at least $3 \%$ of GDP in one year. This is a frequently-employed and preferred single criterion definition of episodes that involve the abrupt reduction of net capital inflows in a particular year. Given the wide range of definitions used in the empirical literature, two additional descriptions of sudden stops are explored: a reduction in one year in net capital inflows of at least $5 \%$ of GDP (sudden stop type B); and of at least $7 \%$ of GDP (sudden stop type C).

\section{Empirical specification and data issues}

Given the prior analytical framework, the final empirical specification takes the following form:

$$
\begin{aligned}
& g r_{i, t}=\alpha_{i}+\underbrace{\beta_{1} G D P p c_{i, t}+\beta_{2} \text { ays }_{i, t}+\beta_{3} \text { popgr }_{i, t}+\beta_{4} \text { open }_{i, t}+\beta_{5} \text { relpinv }_{i, t}}_{\text {CORE EXPLANATORY VARIABLES }} \\
& +\overbrace{\boldsymbol{\beta}_{6} \text { careversals }_{i, t}+\boldsymbol{\beta}_{7} \text { sudstops }_{i, t}}^{\begin{array}{c}
\text { FRAGILITY PERSPETIVE ON THE } \\
\text { CURRENT ACCOUNT ADJUSTMENT }
\end{array}}+\overbrace{\boldsymbol{\beta}_{8} \text { cab }_{i, t}}^{\begin{array}{c}
\text { GROWTH } \\
\text { CURRENT }
\end{array}}
\end{aligned}
$$

$$
+\overbrace{\text { goveons }_{i, t}+f d i_{I, T}+p i_{i, t}+n f a_{i, t}+f i n d e v_{i, t}+\operatorname{agedep}_{i, t}}^{\text {CONTROL }}+u_{i, t}
$$

where $\mathrm{gr}_{\text {it }}$ represents the growth of GDP per capita (in purchasing power parity terms) in multi-year non-overlapping intervals; $\alpha_{i}$ are the unobservable country-specific effects in the selected static fixed-effects panel data model; and $u_{\mathrm{i}, \mathrm{t}}$ is a disturbance term, independently and identically distributed (with mean 0 and variance $\sigma^{2}$ ). The description of the symbols for the explanatory variables and their expected sign is presented in Table 2. 
Table 2 - Symbols, description and expected sign of the explanatory variables

\begin{tabular}{|l|l|c|}
\hline Symbol & Description of the explanatory variable & $\begin{array}{c}\text { Expected } \\
\text { sign }\end{array}$ \\
\hline GDPpc & Initial GDP per capita (in purchasing power parity terms) & - \\
\hline ays & Average years of schooling & + \\
\hline popgr & Annual growth rate of the total population & $+/-$ \\
\hline open & $\begin{array}{l}\text { Initial trade openness (sum of exports and imports, as a percentage } \\
\text { of GDP) }\end{array}$ & + \\
\hline relpinv & Relative price of investment & - \\
\hline careversals & Current account reversal episodes (dummy variables) & $-/ 0$ \\
\hline sudstops & Episodes of sudden stops in net inflows of international capital & $-/ 0$ \\
\hline cab & $\begin{array}{l}\text { Average contemporaneous current account balance (as a percent- } \\
\text { age of GDP) }\end{array}$ & - \\
\hline govcons & General government consumption (as a percentage of GDP) & $-/ 0$ \\
\hline fdi & Net inflows of foreign direct investment (as a percentage of GDP) & + \\
\hline pi & Net inflows of portfolio investment (as a percentage of GDP) & $+/ 0$ \\
\hline nfa & Initial net foreign asset position & $+/-$ \\
\hline findev & $\begin{array}{l}\text { Initial financial development (private sector credit, as a percentage } \\
\text { of GDP) }\end{array}$ & + \\
\hline agedep & $\begin{array}{l}\text { Age dependency ratio (population between 0 and 14 and 65 and } \\
\text { 6ver as percentages of the working age population between 15 and }\end{array}$ & - \\
\hline
\end{tabular}

Note: + implies a positive association; - stands for a negative association; and 0 implies no association. Data sources are provided in Appendix 2.

The earlier empirical work on economic growth has demonstrated that yearly time spans are too short to be appropriate to study growth convergence (e.g. Islam, 1995; 2003). The main reason is that yearly observations are subject to short-term disturbances but there is little (if any) guidance in the literature on the 'appropriate' time span that smoothes fluctuations in the business cycle. Barro (1997), for instance, provides pooled regressions with data spanning more than ten years.

In order to investigate the consistency of the results, the dataset for the presented empirical specification is organised at five-, four- and three-year intervals for the forty economies (see Appendix 1). For instance, in the first case, the dependent variable is defined as a five-year average growth rate of GDP per capita (in PPP terms) in nonoverlapping intervals: 1976-1980; 1981-1985; 1986-1990; 1991-1995; 1996-2000; and 2001-2005. In order to address the problem of potential endogeneity, observations of the core explanatory variables are for the year preceding the non-overlapping interval. However, balance of payments data refer to capital flows and therefore enter the growth 
regression as contemporaneous averages. There is no particular reason why the current account balance or the net international capital flows in the year preceding the interval would influence the average GDP growth rate in the following five years.

Due to particular interest in the external accounts of the European economies, an interactive term (a slope dummy variable) is introduced for the variable of interest i.e. the external current account balances of the thirteen European transition economies. The interpretation of their effects is with respect to the reference group of advanced economies.

\section{Diagnostic tests and estimation results}

The insufficient number of observations for the transition economies when data is organised at five- and four-year intervals precludes the use of a dynamic GMM panel data model. The latter methodology seems to be an appropriate strategy to address growth persistence and the potential endogeneity of a few explanatory variables. For these reasons, the second-best solution is to employ a fixed-effects panel data model as the main estimation technique when data is organised at five- and four-year intervals. There are several arguments that support this empirical strategy: first, the fixed-effects panel data model is considered as an appropriate specification when focusing on a specific set of countries and when the inference is restricted solely to their behaviour (Baltagi, 2005). Second, the Hausmann specification test provides formal support for this estimation technique (Appendix 3).

The results are fairly consistent across the specifications using data constructed at different time spans (Tables 3, 4 and 5). Initial GDP per capita, average years of schooling, initial net foreign assets, age dependency ratio and the interactive term for current account deficits in the transition economies retain a consistent influence on economic growth rates across the different empirical specifications. Furthermore, the coefficients on population growth, the relative price of investment and trade openness are statistically significant only in a few specifications. Foreign direct and portfolio investment, as well as general government consumption, are statistically insignificant factors in economic growth in most empirical specifications, as is the case with most of the dummy variables for episodes of current account reversals and the sudden stops in net international capital inflows. 
Table 3 - Fixed-effects static panel data growth model using data at five-year intervals, 1976-2005

\begin{tabular}{|c|c|c|c|c|c|c|}
\hline \multirow[b]{2}{*}{ Explanatory variables } & \multicolumn{6}{|c|}{ Average 5-year growth of GDP per capita } \\
\hline & $\begin{array}{c}\text { CA reversal } \\
\text { episodes } \\
(3 \% \text { of GDP) }\end{array}$ & $\begin{array}{c}\text { CA reversal } \\
\text { episodes } \\
(4 \% \text { of GDP) }\end{array}$ & $\begin{array}{c}\text { CA reversal } \\
\text { episodes } \\
\text { (5\% of GDP) }\end{array}$ & $\begin{array}{l}\text { Sudden stop of net } \\
\text { capital inflows } \\
\text { (3\% of GDP) }\end{array}$ & $\begin{array}{l}\text { Sudden stop of net } \\
\text { capital inflows } \\
\text { (5\% of GDP) }\end{array}$ & $\begin{array}{c}\text { Sudden stop of net } \\
\text { capital inflows } \\
\text { (7\% of GDP) }\end{array}$ \\
\hline Logarithm of initial GDP per capita (PPP) & $\begin{array}{l}-12.921 * * * \\
(-7.56)\end{array}$ & $\begin{array}{l}-12.599 \\
(-6.79)\end{array}$ & $\begin{array}{l}-12.443 * * * * \\
(-7.28)\end{array}$ & $\begin{array}{c}-11.681 * * * \\
(-6.05)\end{array}$ & $\begin{array}{l}-11.457 * * * \\
(-6.16)\end{array}$ & $\begin{array}{l}-11.257 * * * \\
(-5.87)\end{array}$ \\
\hline Initial average years of schooling & $\begin{array}{l}0.812 * * * \\
(3.87)\end{array}$ & $\begin{array}{l}\mathbf{0 . 8 8 3} \text { **** } \\
(3.70)\end{array}$ & $\begin{array}{l}0.895 \text { *** } \\
(3.69)\end{array}$ & $\begin{array}{l}\mathbf{0 . 8 4 3} \text { **** } \\
(3.40)\end{array}$ & $\begin{array}{l}\mathbf{0 . 8 3 6} \text { *** }^{* *} \\
(3.47)\end{array}$ & $\begin{array}{l}0.796 * * * \\
(3.20)\end{array}$ \\
\hline Initial population growth & $\begin{array}{l}\mathbf{0 . 4 8 5} * \\
(1.70)\end{array}$ & $\begin{array}{l}0.343 \\
(1.12)\end{array}$ & $\begin{array}{l}0.359 \\
(1.19)\end{array}$ & $\begin{array}{l}0.180 \\
(0.56)\end{array}$ & $\begin{array}{l}0.209 \\
(0.64)\end{array}$ & $\begin{array}{l}0.244 \\
(0.72)\end{array}$ \\
\hline Initial trade openness & $\begin{array}{l}0.644 \\
(0.80)\end{array}$ & $\begin{array}{l}0.517 \\
(0.68)\end{array}$ & $\begin{array}{l}0.373 \\
(0.38)\end{array}$ & $\begin{array}{l}0.371 \\
(0.50)\end{array}$ & $\begin{array}{l}0.290 \\
(0.40)\end{array}$ & $\begin{array}{l}0.234 \\
(0.33)\end{array}$ \\
\hline Initial relative price of investment & $\begin{array}{l}-\mathbf{5 . 4 0 7} \\
(-1.80)\end{array}$ & $\begin{array}{l}-6.149 * \\
(-1.95)\end{array}$ & $\begin{array}{l}-\mathbf{6 . 0 6 1} * * \\
(-2.03)\end{array}$ & $\begin{array}{l}-7.364 \text { *** } \\
(-2.36)\end{array}$ & $\begin{array}{l}-7.215^{* *} \\
(-2.28)\end{array}$ & $\begin{array}{l}-7.385 * * \\
(-2.33)\end{array}$ \\
\hline Average current-account-to-GDP ratio & $\begin{array}{l}0.032 \\
(0.72)\end{array}$ & $\begin{array}{l}0.058 \\
(1.27)\end{array}$ & $\begin{array}{l}0.052 \\
(1.09)\end{array}$ & $\begin{array}{l}0.091 \text { ** } \\
(2.06)\end{array}$ & $\begin{array}{l}\mathbf{0 . 0 8 9} * * \\
(2.04)\end{array}$ & $\begin{array}{l}\mathbf{0 . 0 8 7} * \\
(1.96)\end{array}$ \\
\hline $\begin{array}{l}\text { Transition country dummy x Average current } \\
\text {-account-to-GDP ratio }\end{array}$ & $\begin{array}{l}-\mathbf{0 . 4 5 7} * * \\
(-2.26)\end{array}$ & $\begin{array}{l}-\mathbf{0 . 4 1 2} * \\
(-1.90)\end{array}$ & $\begin{array}{l}-\mathbf{0 . 5 2 8} * * * * \\
(-3.02)\end{array}$ & $\begin{array}{l}-\mathbf{0 . 5 6 0 * * *} \\
(-3.11)\end{array}$ & $\begin{array}{l}-0.548 * * * \\
(-3.07)\end{array}$ & $\begin{array}{l}-\mathbf{0 . 5 5 0} * * * \\
(-3.01)\end{array}$ \\
\hline Initial net foreign asset position & $\begin{array}{l}-\mathbf{0 . 9 7 6} * * \\
(-2.10)\end{array}$ & $\begin{array}{l}-1.045 * * \\
(-2.14)\end{array}$ & $\begin{array}{l}-\mathbf{1 . 0 3 7} * * \\
(-2.15)\end{array}$ & $\begin{array}{l}-1.245 * * \\
(-2.43)\end{array}$ & $\begin{array}{l}-1.278 \text { *** } \\
(-2.44)\end{array}$ & $\begin{array}{l}-1.257 * * * \\
(-2.44)\end{array}$ \\
\hline Initial government consumption & $\begin{array}{l}-0.020 \\
(-0.44)\end{array}$ & $\begin{array}{l}-0.031 \\
(-0.62)\end{array}$ & $\begin{array}{l}-0.011 \\
(-0.21)\end{array}$ & $\begin{array}{l}-0.052 \\
(-0.98)\end{array}$ & $\begin{array}{l}-0.054 \\
(-1.08)\end{array}$ & $\begin{array}{l}-0.052 \\
(-0.99)\end{array}$ \\
\hline Average foreign direct investment, net & $\begin{array}{r}-0.035 \\
(-0.56)\end{array}$ & $\begin{array}{l}-0.034 \\
(-0.51)\end{array}$ & $\begin{array}{l}-0.042 \\
(-0.61)\end{array}$ & $\begin{array}{l}-0.021 \\
(-0.28)\end{array}$ & $\begin{array}{r}-0.026 \\
(-0.36)\end{array}$ & $\begin{array}{l}-0.035 \\
(-0.47)\end{array}$ \\
\hline Average portfolio investment, net & $\begin{array}{l}-0.019 \\
(-0.64)\end{array}$ & $\begin{array}{l}-0.021 \\
(-0.68)\end{array}$ & $\begin{array}{l}-0.019 \\
(-0.62)\end{array}$ & $\begin{array}{l}-0.017 \\
(-0.56)\end{array}$ & $\begin{array}{l}-0.015 \\
(-0.47)\end{array}$ & $\begin{array}{l}-0.008 \\
(-0.26)\end{array}$ \\
\hline Initial age dependency ratio & $\begin{array}{l}-0.216 * * * \\
(-3.98)\end{array}$ & $\begin{array}{l}-0.216 * * * \\
(-3.61)\end{array}$ & $\begin{array}{l}-0.210 * * * \\
(-3.83)\end{array}$ & $\begin{array}{l}-\mathbf{0 . 2 3 5} * * * \\
(-4.04)\end{array}$ & $\begin{array}{l}-\mathbf{0 . 2 2 9} * * * \\
(-4.01)\end{array}$ & $\begin{array}{l}-0.225 * * * \\
(-3.86)\end{array}$ \\
\hline Initial financial development & $\begin{array}{l}0.307 \\
(0.77)\end{array}$ & $\begin{array}{l}0.341 \\
(0.84)\end{array}$ & $\begin{array}{l}0.301 \\
(0.73)\end{array}$ & $\begin{array}{l}0.157 \\
(0.33)\end{array}$ & $\begin{array}{l}0.200 \\
(0.46)\end{array}$ & $\begin{array}{l}0.235 \\
(0.49)\end{array}$ \\
\hline \multicolumn{7}{|l|}{ Current account reversals (dummy variables) } \\
\hline Definition $\mathrm{A}(\mathrm{CAB}=-3 \% ;$ Improvement $=3 \%)$ & $\begin{array}{l}-1.164 * * * \\
(-2.93)\end{array}$ & & & & & \\
\hline Definition $\mathrm{B}(\mathrm{CAB}=-4 \%$; Improvement $=4 \%)$ & & $\begin{array}{l}-0.579 \\
(-1.21)\end{array}$ & & & & \\
\hline Definition $\mathrm{C}(\mathrm{CAB}=-5 \%$; Improvement $=5 \%)$ & & & $\begin{array}{l}-0.998 \\
(-1.43)\end{array}$ & & & \\
\hline \multicolumn{7}{|l|}{ Sudden stops (dummy variables) } \\
\hline Definition A (Reduction of $3 \%$ of GDP) & & & & $\begin{array}{r}-0.255 \\
(-0.79)\end{array}$ & & \\
\hline Definition B (Reduction of $5 \%$ of GDP) & & & & & $\begin{array}{l}-0.195 \\
(-0.68)\end{array}$ & \\
\hline Definition C (Reduction of $7 \%$ of GDP) & & & & & & $\begin{array}{l}-0.149 \\
(-0.49)\end{array}$ \\
\hline \multicolumn{7}{|l|}{ Period effects } \\
\hline Dummy variable $1976-1980$ & $\begin{array}{l}-\mathbf{0 . 9 2 8} * * \\
(-2.20)\end{array}$ & $\begin{array}{l}-\mathbf{0 . 9 7 1} * * \\
(-2.06)\end{array}$ & $\begin{array}{l}-1.103 \\
(-2.25)\end{array}$ & $\begin{array}{l}-1.136 \text { *** } \\
(-2.66)\end{array}$ & $\begin{array}{l}-1.170 * * * \\
(-2.76)\end{array}$ & $\begin{array}{l}-1.182 * * * \\
(-2.79)\end{array}$ \\
\hline Dummy variable 1981-1985 & $\begin{array}{l}0.337 \\
(0.65)\end{array}$ & $\begin{array}{l}0.330 \\
(0.57)\end{array}$ & $\begin{array}{l}0.282 \\
(0.47)\end{array}$ & $\begin{array}{l}0.159 \\
(0.30)\end{array}$ & $\begin{array}{l}0.138 \\
(0.26)\end{array}$ & $\begin{array}{l}0.086 \\
(0.16)\end{array}$ \\
\hline Dummy variable $1986-1990$ & $\begin{array}{r}-0.217 \\
(-0.34)\end{array}$ & $\begin{array}{l}-0.321 \\
(-0.45)\end{array}$ & $\begin{array}{l}-0.363 \\
(-0.50)\end{array}$ & $\begin{array}{l}-0.516 \\
(-0.82)\end{array}$ & $\begin{array}{l}-0.616 \\
(-1.03)\end{array}$ & $\begin{array}{l}-0.747 \\
(-1.23)\end{array}$ \\
\hline Dummy variable 1991-1995 & $\begin{array}{l}1.008 \\
(1.21)\end{array}$ & $\begin{array}{l}0.828 \\
(0.92)\end{array}$ & $\begin{array}{l}0.783 \\
(0.85)\end{array}$ & $\begin{array}{l}0.495 \\
(0.63)\end{array}$ & $\begin{array}{l}0.390 \\
(0.51)\end{array}$ & $\begin{array}{l}0.320 \\
(0.41)\end{array}$ \\
\hline Dummy variable $1996-2000$ & $\begin{array}{l}1.668 \\
(1.65)\end{array}$ & $\begin{array}{l}1.369 \\
(1.27)\end{array}$ & $\begin{array}{l}1.364 \\
(1.25)\end{array}$ & $\begin{array}{l}0.991 \\
(1.00)\end{array}$ & $\begin{array}{l}0.877 \\
(0.94)\end{array}$ & $\begin{array}{l}0.747 \\
(0.79)\end{array}$ \\
\hline Intercept & $\begin{array}{l}133.49 \\
(7.49)\end{array}$ & $\begin{array}{c}131.00 \\
(6.68)\end{array}$ & $\begin{array}{l}128.75 * * * \\
(7.33)\end{array}$ & $\begin{array}{l}125.79 \text { **** } \\
(6.28)\end{array}$ & $\begin{array}{l}123.37^{* * *} \\
(6.35)\end{array}$ & $\begin{array}{c}121.731 \\
(6.09)\end{array}$ \\
\hline Number of observations & 144 & 144 & 144 & 144 & 144 & 144 \\
\hline Number of countries & 28 & 28 & 28 & 28 & 28 & 28 \\
\hline R-squared & 0.608 & 0.608 & 0.616 & 0.570 & 0.568 & 0.567 \\
\hline
\end{tabular}

Notes: $t$-statistics in brackets, based on robust standard errors

Asterisks ***, **, and $*$ indicate $1 \%, 5 \%$ and $10 \%$ levels of significance 
Table 4 - Fixed-effects static panel data growth model using data at four-year intervals, 1976-2005

\begin{tabular}{|c|c|c|c|c|c|c|}
\hline \multirow[b]{2}{*}{ Explanatory variables } & \multicolumn{6}{|c|}{ Average 4-year growth of GDP per capita } \\
\hline & $\begin{array}{c}\text { CA reversal } \\
\text { episodes } \\
\text { (3\% of GDP) }\end{array}$ & $\begin{array}{c}\text { CA reversal } \\
\text { episodes } \\
(4 \% \text { of GDP) }\end{array}$ & $\begin{array}{c}\text { CA reversal } \\
\text { episodes } \\
\text { (5\% of GDP) }\end{array}$ & $\begin{array}{l}\text { Sudden stop of net } \\
\text { capital inflows } \\
\text { ( } 3 \% \text { of GDP) }\end{array}$ & $\begin{array}{l}\text { Sudden stop of net } \\
\text { capital inflows } \\
\text { (5\% of GDP) }\end{array}$ & $\begin{array}{l}\text { Sudden stop of net } \\
\text { capital inflows } \\
\text { (7\% of GDP) }\end{array}$ \\
\hline Logarithm of initial GDP per capita (PPP) & $\begin{array}{l}-10.059 * * * \\
(-6.58)\end{array}$ & $\begin{array}{c}-10.105 \text { *** } \\
(-6.51)\end{array}$ & $\begin{array}{l}-10.026 \text { **** } \\
(-6.43)\end{array}$ & $\begin{array}{l}-\mathbf{9 . 6 3 2} \\
(-6.47)\end{array}$ & $\begin{array}{l}-\mathbf{9 . 6 3 4} \\
(-6.44)\end{array}$ & $\begin{array}{l}-\mathbf{9 . 7 2 7} \text { **** } \\
(-6.46)\end{array}$ \\
\hline Initial average years of schooling & $\begin{array}{l}1.018 \text { *** } \\
(3.52)\end{array}$ & $\begin{array}{l}\mathbf{1 . 0 4 4} * * * \\
(3.62)\end{array}$ & $\begin{array}{l}\mathbf{1 . 0 4 8} \\
(3.67)\end{array}$ & $\begin{array}{l}0.952 * * * \\
(3.33)\end{array}$ & $\begin{array}{l}\mathbf{0 . 9 7 5} * * * \\
(3.42)\end{array}$ & $\begin{array}{l}0.981 * * * \\
(3.46)\end{array}$ \\
\hline Initial population growth & $\begin{array}{l}0.019 \\
(0.06)\end{array}$ & $\begin{array}{l}-0.020 \\
(-0.07)\end{array}$ & $\begin{array}{l}-0.081 \\
(-0.29)\end{array}$ & $\begin{array}{l}-0.026 \\
(-0.09)\end{array}$ & $\begin{array}{l}-0.038 \\
(-0.13)\end{array}$ & $\begin{array}{l}-0.035 \\
(-0.12)\end{array}$ \\
\hline Initial trade openness & $\begin{array}{l}0.144 \\
(0.13)\end{array}$ & $\begin{array}{l}0.164 \\
(0.15)\end{array}$ & $\begin{array}{l}0.185 \\
(0.16)\end{array}$ & $\begin{array}{l}0.195 \\
(0.17)\end{array}$ & $\begin{array}{l}0.126 \\
(0.11)\end{array}$ & $\begin{array}{l}0.108 \\
(0.09)\end{array}$ \\
\hline Initial relative price of investment & $\begin{array}{l}\mathbf{- 3 . 0 6 6} * * * \\
(-3.81)\end{array}$ & $\begin{array}{l}\mathbf{- 3 . 1 3 5} * * * \\
(-4.08)\end{array}$ & $\begin{array}{l}-2.923 \text { *** } \\
(-3.84)\end{array}$ & $\begin{array}{l}\mathbf{- 3 . 1 9 5} * * * \\
(-4.09)\end{array}$ & $\begin{array}{l}\mathbf{- 3 . 2 6 7} * * * \\
(-4.21)\end{array}$ & $\begin{array}{l}\mathbf{- 3 . 1 9 8} * * * \\
(-4.13)\end{array}$ \\
\hline Average current-account-to-GDP ratio & $\begin{array}{l}0.059 \\
(1.56)\end{array}$ & $\begin{array}{l}0.064 \\
(1.59)\end{array}$ & $\begin{array}{l}0.057 \\
(1.41)\end{array}$ & $\begin{array}{l}\mathbf{0 . 0 7 4} * \\
(1.83)\end{array}$ & $\begin{array}{l}\mathbf{0 . 0 7 2} * \\
(1.78)\end{array}$ & $\begin{array}{l}\mathbf{0 . 0 7 4} * \\
(1.82)\end{array}$ \\
\hline $\begin{array}{l}\text { Transition country dummy x Average current } \\
\text {-account-to-GDP ratio }\end{array}$ & $\begin{array}{l}-\mathbf{0 . 3 2 3} \\
(-1.94)\end{array}$ & $\begin{array}{l}-\mathbf{0 . 3 1 6} * \\
(-1.81)\end{array}$ & $\begin{array}{l}-\mathbf{0 . 3 2 2} * * \\
(-1.96)\end{array}$ & $\begin{array}{l}-\mathbf{0 . 3 3 5} \text { ** } \\
(-2.01)\end{array}$ & $\begin{array}{l}-\mathbf{0 . 3 3 0} \\
(-1.95)\end{array}$ & $\begin{array}{l}-\mathbf{0 . 3 4 2} * * \\
(-2.04)\end{array}$ \\
\hline Initial net foreign asset position & $\begin{array}{l}-1.436 \text { ** } \\
(-2.37)\end{array}$ & $\begin{array}{l}-1.452 \\
(-2.32)\end{array}$ & $\begin{array}{l}-1.400 \\
(-2.26)\end{array}$ & $\begin{array}{l}-1.524 * * \\
(-2.56)\end{array}$ & $\begin{array}{l}-1.519 * * \\
(-2.51)\end{array}$ & $\begin{array}{l}-1.534 * * \\
(-2.56)\end{array}$ \\
\hline Initial government consumption & $\begin{array}{r}-0.0003 \\
(-0.00)\end{array}$ & $\begin{array}{l}-0.006 \\
(-0.09)\end{array}$ & $\begin{array}{r}-0.0001 \\
(-0.00)\end{array}$ & $\begin{array}{r}0.0004 \\
(0.01)\end{array}$ & $\begin{array}{l}-0.009 \\
(-0.14)\end{array}$ & $\begin{array}{l}-0.009 \\
(-0.15)\end{array}$ \\
\hline Average foreign direct investment, net & $\begin{array}{r}-0.034 \\
(-0.62)\end{array}$ & $\begin{array}{l}-0.037 \\
(-0.66)\end{array}$ & $\begin{array}{r}-0.040 \\
(-0.71)\end{array}$ & $\begin{array}{l}-0.034 \\
(-0.61)\end{array}$ & $\begin{array}{l}-0.037 \\
(-0.64)\end{array}$ & $\begin{array}{l}-0.038 \\
(-0.65)\end{array}$ \\
\hline Average portfolio investment, net & $\begin{array}{l}0.010 \\
(0.42)\end{array}$ & $\begin{array}{l}0.011 \\
(0.49)\end{array}$ & $\begin{array}{l}0.016 \\
(0.69)\end{array}$ & $\begin{array}{l}0.009 \\
(0.38)\end{array}$ & $\begin{array}{l}0.009 \\
(0.41)\end{array}$ & $\begin{array}{l}0.008 \\
(0.37)\end{array}$ \\
\hline Initial age dependency ratio & $\begin{array}{l}-\mathbf{0 . 1 8 8} * * * \\
(-3.57)\end{array}$ & $\begin{array}{l}-0.193 * * * \\
(-3.75)\end{array}$ & $\begin{array}{l}-0.187^{* * *} \\
(-3.61)\end{array}$ & $\begin{array}{l}-0.186 * * * \\
(-3.68)\end{array}$ & $\begin{array}{l}-0.187 * * * \\
(-3.68)\end{array}$ & $\begin{array}{l}-0.190 * * * \\
(-3.72)\end{array}$ \\
\hline Initial financial development & $\begin{array}{l}-0.258 \\
(-0.55)\end{array}$ & $\begin{array}{l}-0.270 \\
(-0.57)\end{array}$ & $\begin{array}{l}-0.306 \\
(-0.65)\end{array}$ & $\begin{array}{l}-0.435 \\
(-0.93)\end{array}$ & $\begin{array}{l}-0.385 \\
(-0.83)\end{array}$ & $\begin{array}{l}-0.390 \\
(-0.85)\end{array}$ \\
\hline $\begin{array}{l}\text { Current account reversals (dummy variables) } \\
\text { Definition } \mathrm{A}(\mathrm{CAB}=-3 \% ; \text { Improvement }=3 \%)\end{array}$ & $\begin{array}{r}-0.406 \\
(-1.13)\end{array}$ & & & & & \\
\hline Definition $\mathrm{B}(\mathrm{CAB}=-4 \%$; Improvement $=4 \%)$ & & $\begin{array}{l}-0.217 \\
(-0.55)\end{array}$ & & & & \\
\hline Definition $\mathrm{C}(\mathrm{CAB}=-5 \%$; Improvement $=5 \%)$ & & & $\begin{array}{l}-0.645 \\
(-1.20)\end{array}$ & & & \\
\hline Sudden stops (dummy variables) & & & & & & \\
\hline Definition A (Reduction of $3 \%$ of GDP) & & & & $\begin{array}{l}-0.184 \\
(-0.73)\end{array}$ & & \\
\hline Definition B (Reduction of $5 \%$ of GDP) & & & & & $\begin{array}{l}-0.030 \\
(-0.12)\end{array}$ & \\
\hline Definition C (Reduction of 7\% of GDP) & & & & & & $\begin{array}{l}-0.201 \\
(-0.83)\end{array}$ \\
\hline Period effects & & & & & & \\
\hline Dummy variable 1978-1981 & $\begin{array}{r}-0.119 \\
(-0.20)\end{array}$ & $\begin{array}{l}-0.135 \\
(-0.23)\end{array}$ & $\begin{array}{l}-0.120 \\
(-0.20)\end{array}$ & $\begin{array}{l}-0.184 \\
(-0.33)\end{array}$ & $\begin{array}{l}-0.195 \\
(-0.35)\end{array}$ & $\begin{array}{r}-0.193 \\
(-0.34)\end{array}$ \\
\hline Dummy variable $1982-1985$ & $\begin{array}{l}-0.508 \\
(-0.82)\end{array}$ & $\begin{array}{l}-0.554 \\
(-0.89)\end{array}$ & $\begin{array}{l}-0.556 \\
(-0.89)\end{array}$ & $\begin{array}{r}-0.590 \\
(-0.98)\end{array}$ & $\begin{array}{r}-0.630 \\
(-1.04)\end{array}$ & $\begin{array}{l}-0.630 \\
(-1.05)\end{array}$ \\
\hline Dummy variable $1986-1989$ & $\begin{array}{l}0.617 \\
(0.86)\end{array}$ & $\begin{array}{l}0.585 \\
(0.80)\end{array}$ & $\begin{array}{l}0.604 \\
(0.83)\end{array}$ & $\begin{array}{l}0.601 \\
(0.86)\end{array}$ & $\begin{array}{l}0.535 \\
(0.77)\end{array}$ & $\begin{array}{l}0.545 \\
(0.79)\end{array}$ \\
\hline Dummy variable $1990-1993$ & $\begin{array}{l}-0.960 \\
(-1.20)\end{array}$ & $\begin{array}{l}-1.001 \\
(-1.25)\end{array}$ & $\begin{array}{l}-0.947 \\
(-1.19)\end{array}$ & $\begin{array}{l}-0.949 \\
(-1.22)\end{array}$ & $\begin{array}{l}-1.055 \\
(-1.35)\end{array}$ & $\begin{array}{l}-1.037 \\
(-1.36)\end{array}$ \\
\hline Dummy variable 1994-1997 & $\begin{array}{l}0.614 \\
(0.73)\end{array}$ & $\begin{array}{l}0.612 \\
(0.71)\end{array}$ & $\begin{array}{l}0.665 \\
(0.79)\end{array}$ & $\begin{array}{l}0.732 \\
(0.88)\end{array}$ & $\begin{array}{l}0.575 \\
(0.71)\end{array}$ & $\begin{array}{l}0.607 \\
(0.75)\end{array}$ \\
\hline Dummy variable 1998-2001 & $\begin{array}{l}0.993 \\
(1.02)\end{array}$ & $\begin{array}{l}0.938 \\
(0.98)\end{array}$ & $\begin{array}{l}1.032 \\
(1.08)\end{array}$ & $\begin{array}{l}1.011 \\
(1.07)\end{array}$ & $\begin{array}{l}0.822 \\
(0.89)\end{array}$ & $\begin{array}{l}0.872 \\
(0.94)\end{array}$ \\
\hline Dummy variable $2002-2005$ & $\begin{array}{l}1.712 \\
(1.51)\end{array}$ & $\begin{array}{l}1.671 \\
(1.48)\end{array}$ & $\begin{array}{l}1.741 \\
(1.55)\end{array}$ & $\begin{array}{l}1.774 \\
(1.58)\end{array}$ & $\begin{array}{l}1.579 \\
(1.45)\end{array}$ & $\begin{array}{r}1.6587 \\
(1.52)\end{array}$ \\
\hline Intercept & $\begin{array}{l}101.32 \\
(6.63)\end{array}$ & $\begin{array}{c}101.98 \text { *** } \\
(6.55)\end{array}$ & $\begin{array}{c}100.62 \\
(6.42)\end{array}$ & $\begin{array}{l}97.97 * * * \\
(6.53)\end{array}$ & $\begin{array}{l}\mathbf{9 8 . 1 7} \text { **** } \\
(6.51)\end{array}$ & $\begin{array}{l}99.13 * * * \\
(6.51)\end{array}$ \\
\hline Number of observations & 203 & 203 & 203 & 204 & 204 & 204 \\
\hline Number of countries & 40 & 40 & 40 & 40 & 40 & 40 \\
\hline R-squared & 0.496 & 0.492 & 0.497 & 0.490 & 0.488 & 0.490 \\
\hline
\end{tabular}

Notes: $t$-statistics in brackets, based on robust standard errors

Asterisks ***, **, and *indicate $1 \%, 5 \%$ and $10 \%$ levels of significance 
Table 5 - Fixed-effects static panel data growth model using data at three-year intervals, 1976-2005

\begin{tabular}{|c|c|c|c|c|c|c|}
\hline \multirow[b]{2}{*}{ Explanatory variables } & \multicolumn{6}{|c|}{ Average 3-year growth of GDP per capita } \\
\hline & $\begin{array}{c}\text { CA reversal } \\
\text { episodes } \\
(3 \% \text { of GDP) }\end{array}$ & $\begin{array}{c}\text { CA reversal } \\
\text { episodes } \\
(4 \% \text { of GDP) }\end{array}$ & $\begin{array}{l}\text { CA reversal } \\
\text { episodes } \\
\text { (5\% of GDP) }\end{array}$ & $\begin{array}{l}\text { Sudden stop of net } \\
\text { capital inflows } \\
\text { (3\% of GDP) }\end{array}$ & $\begin{array}{l}\text { Sudden stop of net } \\
\text { capital inflows } \\
\text { (5\% of GDP) }\end{array}$ & $\begin{array}{l}\text { Sudden stop of net } \\
\text { capital inflows } \\
\text { (7\% of GDP) }\end{array}$ \\
\hline Logarithm of initial GDP per capita (PPP) & $\begin{array}{l}-10.481 * * * \\
(-5.80)\end{array}$ & $\begin{array}{l}-\mathbf{- 1 0 . 4 3 4} * * * * \\
(-5.77)\end{array}$ & $\begin{array}{c}-10.252 * * * \\
(-5.73)\end{array}$ & $\begin{array}{l}-\mathbf{9 . 5 5 0} * * * \\
(-5.41)\end{array}$ & $\begin{array}{l}-\mathbf{9 . 4 3 0} * * * \\
(-5.36)\end{array}$ & $\begin{array}{l}-\mathbf{9 . 5 9 7} * * * \\
(-5.40)\end{array}$ \\
\hline Initial average years of schooling & $\begin{array}{l}\mathbf{1 . 1 1 7} * * * \\
(3.84)\end{array}$ & $\begin{array}{l}\mathbf{1 . 1 6 2} * * * \\
(3.95)\end{array}$ & $\begin{array}{l}\mathbf{1 . 1 5 1} * * * \\
(3.92)\end{array}$ & $\begin{array}{l}0.999 * * * \\
(3.48)\end{array}$ & $\begin{array}{l}\mathbf{1 . 0 2 7} * * * \\
(3.55)\end{array}$ & $\begin{array}{l}\mathbf{1 . 0 2 3} * * * \\
(3.55)\end{array}$ \\
\hline Initial population growth & $\begin{array}{l}0.416 \\
(1.48)\end{array}$ & $\begin{array}{l}0.369 \\
(1.34)\end{array}$ & $\begin{array}{l}0.285 \\
(1.09)\end{array}$ & $\begin{array}{l}0.319 \\
(1.17)\end{array}$ & $\begin{array}{l}0.319 \\
(1.17)\end{array}$ & $\begin{array}{l}0.330 \\
(1.20)\end{array}$ \\
\hline Initial trade openness & $\begin{array}{l}-2.622 * \\
(-1.86)\end{array}$ & $\begin{array}{l}-2.413 \\
(-1.69)\end{array}$ & $\begin{array}{l}-2.313 \\
(-1.59)\end{array}$ & $\begin{array}{l}-2.007 \\
(-1.38)\end{array}$ & $\begin{array}{l}-2.030 \\
(-1.41)\end{array}$ & $\begin{array}{l}-1.952 \\
(-1.36)\end{array}$ \\
\hline Initial relative price of investment & $\begin{array}{l}-0.653 \\
(-0.83)\end{array}$ & $\begin{array}{l}-0.623 \\
(-0.78)\end{array}$ & $\begin{array}{r}-0.644 \\
(-0.86)\end{array}$ & $\begin{array}{r}-0.654 \\
(-0.80)\end{array}$ & $\begin{array}{r}-0.805 \\
(-0.95)\end{array}$ & $\begin{array}{l}-0.717 \\
(-0.87)\end{array}$ \\
\hline Average current-account-to-GDP ratio & $\begin{array}{l}0.020 \\
(0.59)\end{array}$ & $\begin{array}{l}0.022 \\
(0.59)\end{array}$ & $\begin{array}{l}0.021 \\
(0.58)\end{array}$ & $\begin{array}{l}0.046 \\
(1.26)\end{array}$ & $\begin{array}{l}0.041 \\
(1.14)\end{array}$ & $\begin{array}{l}0.043 \\
(1.19)\end{array}$ \\
\hline $\begin{array}{l}\text { Transition country dummy x Average current } \\
\text {-account-to-GDP ratio }\end{array}$ & $\begin{array}{l}-0.204 \\
(-1.56)\end{array}$ & $\begin{array}{l}-0.201 \\
(-1.49)\end{array}$ & $\begin{array}{l}-0.238 * \\
(-1.87)\end{array}$ & $\begin{array}{l}-0.263 * \\
(-2.01)\end{array}$ & $\begin{array}{l}-0.241 * \\
(-1.85)\end{array}$ & $\begin{array}{l}-\mathbf{- 0 . 2 5 4} * \\
(-1.95)\end{array}$ \\
\hline Initial net foreign asset position & $\begin{array}{l}-1.349 * * * \\
(-2.90)\end{array}$ & $\begin{array}{l}-1.367 * * * \\
(-2.91)\end{array}$ & $\begin{array}{l}-1.325 * * * \\
(-2.87)\end{array}$ & $\begin{array}{l}-1.406 * * * \\
(-2.98)\end{array}$ & $\begin{array}{l}-1.354 * * * \\
(-2.91)\end{array}$ & $\begin{array}{l}-1.361 * * * \\
(-2.90)\end{array}$ \\
\hline Initial government consumption & $\begin{array}{l}-0.040 \\
(-0.63)\end{array}$ & $\begin{array}{l}-0.044 \\
(-0.69)\end{array}$ & $\begin{array}{l}-0.043 \\
(-0.67)\end{array}$ & $\begin{array}{l}-0.072 \\
(-1.08)\end{array}$ & $\begin{array}{l}-0.081 \\
(-1.22)\end{array}$ & $\begin{array}{l}-0.080 \\
(-1.21)\end{array}$ \\
\hline Average foreign direct investment, net & $\begin{array}{r}-0.022 \\
(-0.43)\end{array}$ & $\begin{array}{l}-0.019 \\
(-0.38)\end{array}$ & $\begin{array}{r}-0.022 \\
(0.43)\end{array}$ & $\begin{array}{r}0.000 \\
(-0.00)\end{array}$ & $\begin{array}{r}-0.014 \\
(-0.29)\end{array}$ & $\begin{array}{l}-0.004 \\
(-0.09)\end{array}$ \\
\hline Average portfolio investment, net & $\begin{array}{l}0.015 \\
(0.61)\end{array}$ & $\begin{array}{l}0.014 \\
(0.58)\end{array}$ & $\begin{array}{l}0.015 \\
(0.59)\end{array}$ & $\begin{array}{l}0.007 \\
(0.31)\end{array}$ & $\begin{array}{l}0.012 \\
(0.48)\end{array}$ & $\begin{array}{l}0.007 \\
(0.29)\end{array}$ \\
\hline Initial age dependency ratio & $\begin{array}{l}-\mathbf{0 . 1 8 8} * * * \\
(-3.33)\end{array}$ & $\begin{array}{l}-0.191 * * * \\
(-3.38)\end{array}$ & $\begin{array}{r}-0.184 \\
(-3.25)\end{array}$ & $\begin{array}{l}-\mathbf{0 . 1 7 0 * * *} \\
(-3.07)\end{array}$ & $\begin{array}{l}-0.169 * * * \\
(-3.06)\end{array}$ & $\begin{array}{r}-0.174 \\
(-3.10)\end{array}$ \\
\hline Initial financial development & $\begin{array}{l}-0.679 \\
(-1.22)\end{array}$ & $\begin{array}{l}-0.626 \\
(-1.13)\end{array}$ & $\begin{array}{l}-0.704 \\
(-1.26)\end{array}$ & $\begin{array}{l}-0.895 \\
(-1.60)\end{array}$ & $\begin{array}{l}-0.897 \\
(-1.60)\end{array}$ & $\begin{array}{l}-0.881 \\
(-1.58)\end{array}$ \\
\hline $\begin{array}{l}\text { Current account reversals (dummy variables) } \\
\quad \text { Definition } \mathrm{A}(\mathrm{CAB}=-3 \% ; \text { Improvement }=3 \%)\end{array}$ & $\begin{array}{l}-0.922 \text { ** } \\
(-2.26)\end{array}$ & & & & & \\
\hline Definition $\mathrm{B}(\mathrm{CAB}=-4 \%$; Improvement $=4 \%)$ & & $\begin{array}{l}-\mathbf{- 0 . 7 8 0} * \\
(-1.76)\end{array}$ & & & & \\
\hline Definition $\mathrm{C}(\mathrm{CAB}=-5 \%$; Improvement $=5 \%)$ & & & $\begin{array}{l}-0.911 \\
(-1.40)\end{array}$ & & & \\
\hline Sudden stops (dummy variables) & & & & & & \\
\hline Definition A (Reduction of $3 \%$ of GDP) & & & & $\begin{array}{l}-0.273 \\
(-1.03)\end{array}$ & & \\
\hline Definition B (Reduction of $5 \%$ of GDP) & & & & & $\begin{array}{l}-0.239 \\
(-1.00)\end{array}$ & \\
\hline Definition C (Reduction of $7 \%$ of GDP) & & & & & & $\begin{array}{l}-0.170 \\
(-0.69)\end{array}$ \\
\hline Period effects & & & & & & \\
\hline Dummy variable 1976-1978 & $\begin{array}{l}0.376 \\
(0.69)\end{array}$ & $\begin{array}{l}0.253 \\
(0.47)\end{array}$ & $\begin{array}{l}0.361 \\
(0.64)\end{array}$ & $\begin{array}{l}0.672 \\
(1.29)\end{array}$ & $\begin{array}{l}0.669 \\
(1.28)\end{array}$ & $\begin{array}{l}0.664 \\
(1.27)\end{array}$ \\
\hline Dummy variable 1979-1981 & $\begin{array}{l}-0.104 \\
(-0.15)\end{array}$ & $\begin{array}{l}-0.153 \\
(-0.22)\end{array}$ & $\begin{array}{l}-0.075 \\
(-0.11)\end{array}$ & $\begin{array}{l}0.039 \\
(0.06)\end{array}$ & $\begin{array}{r}0.0001 \\
(0.00)\end{array}$ & $\begin{array}{l}0.005 \\
(0.01)\end{array}$ \\
\hline Dummy variable 1982-1984 & $\begin{array}{l}-0.372 \\
(-0.59)\end{array}$ & $\begin{array}{l}-0.473 \\
(-0.76)\end{array}$ & $\begin{array}{l}-0.498 \\
(-0.77)\end{array}$ & $\begin{array}{l}-0.338 \\
(-0.59)\end{array}$ & $\begin{array}{l}-0.410 \\
(-0.71)\end{array}$ & $\begin{array}{l}-0.396 \\
(-0.69)\end{array}$ \\
\hline Dummy variable 1985-1987 & $\begin{array}{l}0.572 \\
(0.79)\end{array}$ & $\begin{array}{l}0.500 \\
(0.70)\end{array}$ & $\begin{array}{l}0.594 \\
(0.81)\end{array}$ & $\begin{array}{l}0.679 \\
(1.07)\end{array}$ & $\begin{array}{l}0.591 \\
(0.93)\end{array}$ & $\begin{array}{l}0.621 \\
(0.97)\end{array}$ \\
\hline Dummy variable $1988-1990$ & $\begin{array}{l}1.022 \\
(1.24)\end{array}$ & $\begin{array}{l}0.901 \\
(1.10)\end{array}$ & $\begin{array}{l}0.990 \\
(1.20)\end{array}$ & $\begin{array}{l}1.210 \\
(1.65)\end{array}$ & $\begin{array}{l}1.012 \\
(1.40)\end{array}$ & $\begin{array}{l}1.093 \\
(1.51)\end{array}$ \\
\hline Dummy variable 1991-1993 & $\begin{array}{l}-0.785 \\
(-0.87)\end{array}$ & $\begin{array}{l}-0.927 \\
(-1.06)\end{array}$ & $\begin{array}{l}-0.811 \\
(-0.91)\end{array}$ & $\begin{array}{l}-0.663 \\
(-0.84)\end{array}$ & $\begin{array}{l}-0.925 \\
(-1.20)\end{array}$ & $\begin{array}{l}-0.791 \\
(-1.03)\end{array}$ \\
\hline Dummy variable 1994-1996 & $\begin{array}{l}0.900 \\
(0.97)\end{array}$ & $\begin{array}{l}0.815 \\
(0.88)\end{array}$ & $\begin{array}{l}0.935 \\
(1.01)\end{array}$ & $\begin{array}{l}1.239 \\
(1.46)\end{array}$ & $\begin{array}{l}0.965 \\
(1.20)\end{array}$ & $\begin{array}{l}1.069 \\
(1.31)\end{array}$ \\
\hline Dummy variable 1997-1999 & $\begin{array}{l}1.394 \\
(1.41)\end{array}$ & $\begin{array}{l}1.263 \\
(1.32)\end{array}$ & $\begin{array}{l}1.325 \\
(1.36)\end{array}$ & $\begin{array}{l}\mathbf{1 . 4 3 4} \text { * } \\
(1.71)\end{array}$ & $\begin{array}{l}1.160 \\
(1.42)\end{array}$ & $\begin{array}{l}1.255 \\
(1.52)\end{array}$ \\
\hline Dummy variable 2000-2002 & $\begin{array}{l}1.892 \\
(1.62)\end{array}$ & $\begin{array}{l}1.686 \\
(1.52)\end{array}$ & $\begin{array}{l}1.746 \\
(1.56)\end{array}$ & $\begin{array}{l}1.912 * \\
(1.91)\end{array}$ & $\begin{array}{l}1.541 \\
(1.62)\end{array}$ & $\begin{array}{l}\mathbf{1 . 7 2 4} * \\
(1.79)\end{array}$ \\
\hline Dummy variable 2003-2005 & $\begin{array}{l}\mathbf{2 . 9 8 5} * * \\
(2.38)\end{array}$ & $\begin{array}{l}2.792 * * \\
(2.31)\end{array}$ & $\begin{array}{l}2.886 * * \\
(2.36)\end{array}$ & $\begin{array}{l}3.065 * * * \\
(2.78)\end{array}$ & $\begin{array}{l}\mathbf{2 . 6 6 4} * * \\
(2.57)\end{array}$ & $\begin{array}{l}\mathbf{2 . 8 4 1} 1^{* * *} \\
(2.70)\end{array}$ \\
\hline Intercept & $\begin{array}{l}104.70 \text { *** } \\
(5.79)\end{array}$ & $\begin{array}{l}103.93 * * * \\
(5.73)\end{array}$ & $\begin{array}{l}101.89 \text { *** } \\
(5.70)\end{array}$ & $\begin{array}{l}\mathbf{9 6 . 1 2} * * * \\
(5.38)\end{array}$ & $\begin{array}{l}\mathbf{9 5 . 1 7} \\
(5.35)\end{array}$ & $\begin{array}{l}96.78^{* * *} \\
(5.36)\end{array}$ \\
\hline Number of observations & 277 & 277 & 277 & 281 & 281 & 281 \\
\hline Number of countries & 40 & 40 & 40 & 40 & 40 & 40 \\
\hline R-squared & 0.366 & 0.355 & 0.354 & 0.347 & 0.346 & 0.344 \\
\hline
\end{tabular}

Notes: t-statistics in brackets, based on robust standard errors

Asterisks ***, **, and $*$ indicate $1 \%, 5 \%$ and $10 \%$ levels of significance 
The estimation results from the empirical specification using data organised at a five-year interval are simply interpreted (column 1 of Table 3 ). In line with the betaconvergence hypothesis, initial per capita income is negatively correlated with economic growth. This implies that an increase in initial per capita income of 1 per cent is associated with, on average, a rate of longer-term growth of GDP per capita which is lower by 0.13 percentage points in the analysed economies. The impact of human capital, captured by the average years of schooling variable, is also strong: an additional six months of schooling (say from 8.42 years, which is the average for the sample during the observed period, to 8.92 years) would increase the average GDP growth rate by 0.41 percentage points $(0.812 / 2)$, other things being equal. If the price level of investment increases by 0.1 percentage points more than the GDP deflator, then, on average, the longer-term economic growth rate is expected to decelerate by 0.54 percentage points. Furthermore, a deterioration in the net foreign asset position by 1 percentage point of GDP leads to an increase in the longer-term economic growth rate of 0.01 percentage points. Unlike population growth, age dependency plays an important role: an increase in the age dependency ratio by 1 percentage point is estimated to lead, on average, to a deceleration in the average growth rate of 0.216 percentage points, ceteris paribus.

Lastly, the coefficients of interest are statistically significant and reveal a strong and consistent impact of current account deficits on economic growth. A one percentage point deterioration in the current account balance to GDP ratio in transition economies is estimated to lead to a rate of economic growth which is higher by 0.42 percentage points $[-0.003+(-0.457)]$. The magnitude of the coefficient is slightly higher than that obtained in the similar study by Prasad et al. (2007) which produced an estimate of -0.35 . Additionally, only current account reversals associated with an initial current account deficit of at least $3 \%$ of GDP, and a magnitude of reduction of at least $3 \%$ of GDP, exhibit growth-detrimental effects, i.e. a reduction in the five-year growth rate of GDP per capita by 1.2 percentage points, ceteris paribus. The coefficient is the same size as in the study by Melecky (2005), who used annual data and who defined current account reversal as an improvement in the current account balance of at least $2.5 \%$ of GDP.

Due to the small number of observations, particularly for transition economies, the estimates based on five-year non-overlapping intervals are likely to suffer from increased variance in the smaller sample. In order to check their consistency, the same regression is run with data organised at four-year and three-year intervals (Tables 4 and 5).

The estimation results provide evidence of a consistent influence on longer-term economic growth of initial income per capita, average years of schooling, net foreign assets, current account deficits in transition economies and age dependency. However, only the coefficients on the variables of interest are interpreted in what follows. The coefficient on the interactive term for the current account deficits of transition economies is statistically significant at the $5 \%$ and $10 \%$ level in all but two empirical specifications, and in a range of between 0.24 and 0.56 percentage points of GDP. Hence, there is evidence that transition countries have moderately speeded up the convergence process by running larger current account deficits. Additionally, only the 
dummy variables for current account reversal definitions A and B (current account deficits in excess of $3 \%$ and $4 \%$ of GDP, respectively) are statistically significant (at the $5 \%$ and $10 \%$ level, respectively) in the estimation based on data organised at threeyear intervals. These suggest that such current account adjustment episodes are likely to lead to a reduction in the average three-year economic growth rate of respectively 0.92 and 0.78 percentage points. The other definitions of current account reversals and sudden stops in net international capital inflows do not exhibit any significant influence on growth performance. Put differently, there is thus some limited evidence to suggest that current account reversals have been associated with statistically significant slowdowns in economic growth.

The explanation behind the resilience of European economies to current account reversals and sudden stops is partly associated with the comfortable level of international reserves. For example, a positive and strong association between these two variables would suggest that reductions in net capital inflows have been matched by a depletion of foreign exchange reserves, and vice versa. Table 6 reveals that the coefficients of correlation between total foreign exchange reserves (minus gold) and net capital inflows, both expressed in terms of GDP, were 0.678 and 0.302 for south-east and central and east European transition economies respectively during the 1992-2005 period.

Table 6 - The correlation between current account adjustment episodes and level of foreign exchange reserves

\begin{tabular}{|l|c|c|c|c|c|c|}
\hline Group of & \multirow{2}{*}{$\begin{array}{c}\text { Correlation } \\
\text { economies }\end{array}$} & \multirow{2}{*}{$\begin{array}{c}\text { Pairs of } \\
\text { observat } \\
\text { ions }\end{array}$} & \multirow{2}{*}{$\begin{array}{c}\text { p- } \\
\text { value }\end{array}$} & \multicolumn{3}{|c|}{ Current account reversals } \\
\cline { 5 - 7 } & & & $\begin{array}{c}\text { Definition } \\
\text { A }\end{array}$ & $\begin{array}{c}\text { Definition } \\
\text { B }\end{array}$ & $\begin{array}{c}\text { Definition } \\
\text { C }\end{array}$ \\
\hline $\begin{array}{l}\text { South-east } \\
\text { economies }\end{array}$ & 0.6781 & 63 & 0.000 & 15 & 12 & 8 \\
\hline $\begin{array}{l}\text { Central and } \\
\text { east } \\
\text { economies }\end{array}$ & 0.3016 & 105 & 0.002 & 10 & 7 & 3 \\
\hline $\begin{array}{l}\text { EU-13** } \\
\text { economies }\end{array}$ & 0.0541 & 401 & 0.280 & 8 & 2 & 0 \\
\hline
\end{tabular}

* Correlation coefficient between net international capital inflows and total foreign exchange reserves (minus gold)

** EU-15 group, minus Ireland and Luxembourg

Definition $A: C A B=-3 \%$; improvement $=3 \%$

Definition $B: C A B=-4 \%$; improvement $=4 \%$

Definition $C: C A B=-5 \%$; improvement $=5 \%$

There is also supplementary evidence that transition economies have maintained a relatively high level of foreign exchange reserves because they were more prone to current account reversals. The correlation between net international capital inflows and foreign exchange reserves is not statistically different to zero in the case of the thirteen 
advanced EU economies, but this group did not experience many current account adjustment episodes during the 1971-2005 period.

\section{Concluding remarks}

The dramatic increase in the speed of intertemporal trade during the late 1990s and early 2000s ('the age of equity finance'), as seen by widening current account deficits and deteriorating net foreign asset positions, has ignited considerable interest in sustainability analysis. Despite the numerous empirical studies, the only definite policy conclusions are those calling for a cautious monitoring of external imbalances.

This study produces some limited evidence that the observed swings in the current account balance (current account reversals) and sudden stops in net capital inflows have been associated with slowdowns in growth. The literature on external sustainability analysis is in its infancy, so several operational definitions have been employed in order to test the sensitivity of the results. The results are broadly consistent across different empirical specifications and a range of operational definitions. Nevertheless, much additional research is needed to reconsider the practice of arbitrarily determined thresholds for characterising an event such as current account reversals because certain operational definitions have different policy implications.

On the benefit side, large and persistent current account deficits have been associated with gains from intertemporal trade and, therefore, have served as an engine of economic growth. The evidence seems to support the proposition that widening and persistent current account deficits in transition economies have generated, on average, moderate growth-conducive effects. More precisely, a deterioration in the current account to GDP ratio by 1 percentage point is expected to result, on average, on a rate of economic growth which is higher by between 0.24 and 0.56 percentage points. The results are fairly consistent across different empirical specifications using a number of control variables.

However, the world economic turmoil that erupted with the collapse of Lehman Brothers in September 2008, and the unprecedented deterioration in the current account balances of many transition countries in the last decade, warn that it may be reasonable continuously to revisit Bhagwati's (1998) point that the risks of global financial integration may outweigh the benefits. Given rapidly increasing financial integration, sudden shifts in market sentiment and higher variations in current account balances are yet to be seen on the global economic scene.

\section{References}

Abiad, A, D. Leigh and A. Mody (2007) International Finance and Income Convergence: Europe is Different IMF Working Paper No. 64, International Monetary Fund: Washington DC.

AmirKhalkhali, S and A. Dar (2007) 'Trade Openness and Saving-Investment Correlations' Economic Modelling 24(1): 120-127.

Baltagi, B (2005) Econometric Analysis of Panel Data Third Edition, John Wiley \& Sons. 
Barro, R (1990) 'Government Spending in a Simple Model of Endogenous Growth' Journal of Political Economy 98(5) (October), Part II: 103-125.

Barro, R (1997) Determinants of Economic Growth Cambridge, Massachusetts: MIT Press.

Barro, R and J. Lee (2000) International Data on Educational Attainment: Updates and Implications CID Working Paper No. 42, Center for International Development, Harvard University, April.

Barro, R and X. Sala-i-Martin (2001) Economic Growth First Edition, Cambridge, Massachusetts: MIT Press.

Bhagwati, J (1998) 'The Capital Myth’ Foreign Affairs 77(3): 7-12.

Calderón, C, A. Chong and N. Loayza (2002) 'Determinants of Current Account Deficits in Developing Countries' Contributions to Macroeconomics Berkeley Electronic Press Vol. 2(1): 1-31, Article 2.

Campos, N. and Y. Kinoshita (2002) Foreign Direct Investment as Technology Transferred: Some Panel Evidence from the Transition Economies Working Papers Series No. 438, William Davidson Institute, University of Michigan, Stephen M. Ross Business School.

Collins, W and J. Williamson (2001) 'Capital-Goods Prices and Investment, 1870-1950’ Journal of Economic History 61: 59-94 Cambridge University Press.

Durham, B (2004) 'Absorptive Capacity and the Effects of Foreign Direct Investment and Equity Foreign Portfolio Investment on Economic Growth' European Economic Review 48(2), April: 285-306.

Easterly, W and R. Levine (2001) 'It's Not Factor Accumulation: Stylized Facts and Growth Models’ World Bank Economic Review 15 (May): 177-220.

Edison, H, R. Levine, L. Ricci and T. Slok (2002) International Financial Integration and Economic Growth IMF Working Paper No. 02/145, International Monetary Fund: Washington DC.

Guseh, S (1997) 'Government Size and Economic Growth in Developing Countries: A Political-Economy Framework’ Journal of Macroeconomics 19: 175-192.

IMF (2009) World Economic Outlook [online database] October.

Islam, N (1995) 'Growth Empirics: A Panel Data Approach' Quarterly Journal of Economics 110(4): 1127-1170.

Islam, N (2003) 'What Have We Learnt From the Convergence Debate?' Journal of Economic Surveys 17(3): 309-362.

Johnson, G and R. Lee (Eds.) (1987) Population Growth and Economic Development: Issues and Evidence University of Wisconsin Press: Madison, Wisconsin.

Jones, C (1994) 'Economic Growth and the Relative Price of Capital' Journal of Monetary Economics 34(3) December: 359-382. 
Kose, A, E. Prasad, K. Rogoff and S. Wei (2006) Financial Globalization: A Reappraisal IMF Working Paper No. 06/189, International Monetary Fund: Washington DC.

Lane, P and G. Milesi-Ferretti (2006) The External Wealth of Nations Mark II: Revised and Extended Estimates of Foreign Assets and Liabilities, 1970-2004 IMF Working Paper No. 06/69, International Monetary Fund: Washington DC.

Levine, R (1997) 'Financial Development and Economic Growth: Views and Agenda' Journal of Economic Literature 35 (June): 688-726.

Levine, R, N. Loayza and T. Beck (2000) Financial Intermediation and Growth: Causality and Causes Journal of Monetary Economics 46 (August): 31-77.

Lucas, R (1988) 'On the Mechanics of Economic Development' Journal of Monetary Economics 22 (July): 3-42.

Lucas, R (1990) 'Why Doesn't Capital Flow from Rich to Poor Countries?' American Economic Review Papers and Proceedings Vol. 80 (May): 92-96.

Melecky, M (2005) 'The Impact of Current Account Reversals on Growth in Central and Eastern Europe’ Eastern European Economics 43(2) (March-April): 57-72.

Mencinger, J (2003) 'Does Foreign Direct Investment Always Enhance Economic Growth?' Kyklos: International Review for Social Sciences 56(4): 491-508.

Prasad, E, R. Rajan and A Subramanian (2007) 'Foreign Capital and Economic Growth' Brookings Paper on Economic Activity No. 1: 153-209.

Rebelo, S (1991) 'Long-Run Policy Analysis and Long-Run Growth' Journal of Political Economy 99 (June): 500-521.

Restuccia, D and C. Urrutia (2001) 'Relative Prices and Investment Rates' Journal of Monetary Economics 47(1) (February): 93-121.

Romer, P (1990) 'Endogenous Technological Change' Journal of Political Economy 98(5), Part 2 (October): 71-102.

Romer, P (1994) 'The Origins of Endogenous Growth' Journal of Economic Perspectives 8 (Winter): 3-22.

Sala-i-Martin, X, G. Doppelhofer and R. Miller (2004) 'Determinants of Long-term Growth: A Bayesian Averaging of Classical Estimates (BACE) Approach' American Economic Review 94(4): 813-835.

Simon, J (1987) 'Population Growth, Economic Growth and Foreign Aid Cato Journal 7(1) (Spring/Summer) Cato Institute: 159-186. 


\section{Appendices}

Appendix 1 - Sample of countries under investigation

\begin{tabular}{|l|l|}
\hline Groups of countries & List of countries \\
\hline \multirow{3}{*}{27 advanced economies } & Fourteen non-EU countries \\
\cline { 2 - 3 } & $\begin{array}{l}\text { Australia, Canada, Cyprus, Hong Kong SAR, Iceland, Israel, } \\
\text { Japan, Malta, New Zealand, Norway, Republic of Korea, } \\
\text { Singapore, Switzerland and United States }\end{array}$ \\
\cline { 2 - 2 } & Advanced EU-13* economies \\
\cline { 2 - 2 } & $\begin{array}{l}\text { Austria, Belgium, Germany, Greece, Denmark, Italy, Portugal, } \\
\text { France, Finland, The Netherlands, Sweden, Spain, United } \\
\text { Kingdom }\end{array}$ \\
\hline \multirow{2}{*}{ transition economies } & $\begin{array}{l}\text { Thirteen European transition countries } \\
\text { Albania, Bulgaria, Croatia, Czech Republic, Estonia, Hungary, } \\
\text { Latvia, Lithuania, Macedonia, Poland, Romania, Slovakia and } \\
\text { Slovenia }\end{array}$ \\
\hline
\end{tabular}

* Due to the outlying observations for the level of trade openness of Ireland and Luxembourg, these countries are excluded from the EU-15 group.

\section{Appendix 2 - Data sources for the employed variables in the growth model}

\begin{tabular}{|l|l|}
\hline Variables employed & Source \\
\hline $\begin{array}{l}\text { Average real GDP per capita } \\
\text { growth (purchasing power } \\
\text { parity, in \$ 1990) in multi-year } \\
\text { non-overlapping intervals }\end{array}$ & $\begin{array}{l}\text { Author's calculations based on data from Groningen Growth } \\
\text { and Development Centre and the Conference Board's Total } \\
\text { Economy Database, May 2006 http://www.ggdc.net }\end{array}$ \\
\hline $\begin{array}{l}\text { Natural logarithm of GDP per } \\
\text { capita (purchasing power } \\
\text { parity, in \$ 1990) }\end{array}$ & $\begin{array}{l}\text { Groningen Growth and Development Centre and the } \\
\text { Conference Board's Total Economy Database, May 2006 } \\
\text { http://www.ggdc.net }\end{array}$ \\
\hline $\begin{array}{l}\text { Average years of schooling of } \\
\text { the population over 25 }\end{array}$ & $\begin{array}{l}\text { Robert J. Barro and Lee Jong-Wha International Data on } \\
\text { Educational Attainment: Updates and Implications (CID } \\
\text { Working Paper No. 42, April 2000) - human capital updated } \\
\text { files. Data for intervals shorter than five years are imputed, } \\
\text { assuming the same growth rate in the years between the two } \\
\text { cut-off points }\end{array}$ \\
\hline Trade openness & $\begin{array}{l}\text { Alan Heston, Robert Summers and Bettina Aten, Penn World } \\
\text { Table Version 6.2, Center for International Comparisons of } \\
\text { Production, Income and Prices at the University of } \\
\text { Pennsylvania, September 2006 }\end{array}$ \\
\hline Population growth & $\begin{array}{l}\text { World Development Indicators (WDI) 2007, ESDS } \\
\text { International (MIMAS), University of Manchester. }\end{array}$ \\
\hline $\begin{array}{l}\text { Relative prices of investment } \\
\text { goods }\end{array}$ & $\begin{array}{l}\text { Alan Heston, Robert Summers and Bettina Aten, Penn World } \\
\text { Table Version 6.2, Center for International Comparisons of } \\
\text { Production, Income and Prices at the University of } \\
\text { Pennsylvania, September 2006 }\end{array}$ \\
\hline
\end{tabular}




\begin{tabular}{|c|c|}
\hline Variables employed & Source \\
\hline $\begin{array}{l}\text { General government } \\
\text { consumption expenditure }\end{array}$ & $\begin{array}{l}\text { UN common database, United Nations Statistics Division [on- } \\
\text { line database], ST/ESA/STAT/UNCDB/WWW, } 22 \text { February } \\
2008\end{array}$ \\
\hline Net foreign direct investment & $\begin{array}{l}\text { Foreign direct investment, net inflows (\% of GDP) } \\
\text { (BX.KLT.DINV.WD.GD.ZS) and foreign direct investment, } \\
\text { net outflows (\% of GDP) (BM.KLT.DINV.WD.GD.ZS). } \\
\text { Source: International Monetary Fund, International Financial } \\
\text { Statistics and Balance of Payments databases, World Bank, } \\
\text { Global Development Finance and World Bank and OECD GDP } \\
\text { estimates. Accessed through: ESDS International (MIMAS), } \\
\text { University of Manchester. The series is normalised by GDP in } \\
\text { \$m (current prices) }\end{array}$ \\
\hline Net portfolio investment & $\begin{array}{l}\text { Portfolio investment, excluding liabilities, constituting foreign } \\
\text { authorities' reserves (BoP, \$ current) (BN.KLT.PTXL.CD). } \\
\text { Source: International Monetary Fund, Balance of Payments } \\
\text { Statistics Yearbook and data files. Accessed through: ESDS } \\
\text { International (MIMAS), University of Manchester. This series } \\
\text { was divided by GDP in \$m (current prices). } \\
\text { For Slovak Republic, Greece and Ireland, additional data have } \\
\text { been obtained from the websites of their central banks }\end{array}$ \\
\hline Net foreign asset position & $\begin{array}{l}\text { Lane and Milesi-Ferretti's international dataset of the external } \\
\text { wealth of nations (P. Lane and G. Milesi-Ferretti (2006) The } \\
\text { External Wealth of Nations Mark II: Revised and Extended } \\
\text { Estimates of Foreign Assets and Liabilities, 1970-2004 IMF } \\
\text { Working Paper No. 06/69, International Monetary Fund: } \\
\text { Washington DC. http://www.imf.org/external/pubs/ft/wp/ } \\
\text { 2006/data/wp0669.zip. }\end{array}$ \\
\hline $\begin{array}{l}\text { Private sector credit from } \\
\text { deposit money banks and } \\
\text { other monetary institutions }\end{array}$ & $\begin{array}{l}\text { Financial structure dataset of the World Bank (http:// } \\
\text { siteresources.worldbank.org/INTRES/ } \\
\text { Resources/FinStructure_60_05_final.xls) }\end{array}$ \\
\hline Age dependency ratio & $\begin{array}{l}\text { Age dependency ratio (dependents to population of working } \\
\text { age) (SP.POP.DPND). Percentage of the working age } \\
\text { population (15-64) taken by the } 0 \text { to } 14 \text { and the } 65 \text { and above } \\
\text { age groups. Source: World Bank, World Development } \\
\text { Indicators (WDI) November 2007, ESDS International } \\
\text { (MIMAS), University of Manchester. }\end{array}$ \\
\hline
\end{tabular}

\section{Appendix 3 - Selection of the appropriate panel data specification (Hausmann specification test)}

Test: Ho: difference in coefficients not systematic:

$$
\begin{aligned}
& \chi^{2}(12)=(b-B)^{\prime}\left[\left(V_{-} b-V_{-} B\right)^{\wedge}(-1)\right](b-B)=66.20 \\
& \text { Prob }>\chi^{2}=0.0000
\end{aligned}
$$

